extra-European. Hydrophilida not having the same limitation in the two works, I take the Palpicorn families in which that group and the Sphæridiidre are included. There are 22 genera in each catalogue, but Schaum and De Marseul each ignore a genus adopted by the other, and a third name, Cyllidium, is preferred by the French author to the earlier one of Chætarthria. As to the species, seeing that Schaum has about $I, 580$ in the families mentioned above, and De Marseul 2,640, it would not be easy to compare them in a definite form ; but taking Cicin. dela, the second genus of the two catalogues, the first having only one species, which is, I conceive, a fair example of the others, if indeed it has not had more than its share of varieties elevated to the rank of species, we find the 26 species in Schaum identical in names with the same species in De Marseul, except two varieties or species, and a synonym given with a ? by Schaum, which is the right name according to De Marseul.

I would venture to suggest that the synonyms which look so formidable to some of our friends, are principally due to the writers of local faunas, or in some cases to specialists, and that such names have, as a rule, never been adopted, and practically offer no hindrance whatever to the naturalist. A species may be described by an author who is ignorant that it has been previously described, but this is an evil which it is sometimes impossible to avoid, as in the case of almost simultaneous publication ; but in due time the later name is relegated to the list of synonyms and gives little further trouble. It does not seem to me that any change or additions to the present rules of nomen. clature are needed. Naturalists very soon decide on the relative value of names, but always with due regard to the law of priority; it is a misfortune, perhaps, that this law is sometimes pushed too far, as in the case either of forgotten authors, or of doubtful descriptions. The alteration of trivial names from two authors using the same word is a case of very rare occurrence. Francis P. PASCOE

\section{The so-called "Meteor-cloud" of Feb. 5}

Your correspondent, Captain S. P. Oiiver, appears to have been mistaken as to the character of the phenomenon seen by him on February 5, and noticed in NATURE (vol. ix: p. 313). At the hour he has indicated, the somewhat rare phenomenon an auroral arch was formed, which remained visible for about half an hour, and is doubtless the luminous "meteor cloud" seen by him. The description Captain Oliver has given of it is suffciently accurate, though he does not mention that it drifted slowly southward, a well-known characteristic of the phenomenon. Its direction was of course at right angles to the magnetic meridian, and its position in the heavens, as seen from this locality, was more northward than that observed by your correspondent. During the whole time that I observed it, the arch crossed some portion of the constellation Ursa Major, the star $\delta$ Ursæ Majoris being in its midst when first seen, and the entire arch having retreated southward as far as $\zeta$ Urse Majoris before it disappeared. It was of uniform breadth and intensity, and spanned the sky from west to east (magnetic), passing not much to the north of the zenith. Although I have been fortunate enough to have seen auroral arches upon several occasions, and once succeeded in obtaining the spectrum, I have never seen a brighter or more complete arch than this one; but what made it quite unique, at least as far as my experience goes, was the fact that the ordinary aurora with a well-defined "dark segment" was visible in the north-north-west at the same time, from which, at an earlier period, brilliant streamers had proceeded. There were therefore two parallel arches of light at an interval of perhaps $50^{\circ}$ from one another, which the slow movement of the upper one gradually increased. The night was remarkably clear, and the zodiacal light had been plainly visible earlier in the evening.

The Observatory, Durham, Feb. 2I

\section{Aboriginal Australian Artists}

I NOTICED, in one of your latest papers, that some of your readers doubted the ability of Australian, or other low savages, to sketch in the manner of the Vezère people, and I made a copy of a few sketches still found in this neighbourhood engraved on rocks. They consist chiefly of fishes, whales, birds, and a few men; the execution is not so good as when the figures are scratched on blackened bark. I also send you a photograph of a carving in fossil coral from New Guinea, H.M.S. Basilisk has not long ago returned from New Guinea, and brought some splendid weapons, \&c.; also one of the Papuan pigs, which they brought for our collection. It is the most intelligent pig I have ever seen, follows me like a dog, and goes up to the very top of the Museum building, which is about 80 feet high.

I noticed the, to me, wonderful remark about a scarcity of skeletons of large carnivora in European museums, and I am glad to say that we possess two tigers, two lions, wolf, hyæna, three grey seals, two large sperm whales, 70 and 35 feet in length, many small birds, dugongs, \&c. \&c. The sum total of our skeletons, all meunted, is more than 150 ; with tew exceptions all articulated on the premises by one man, who has never been out of Sydney in his life. If our Governinent grant some extra money for cabinets, I think we shall bo able to astonish the people on board the Challenger when they come here, because half our Australian fossils and minerals cannot be exhibited for want of the necessary cases.

\section{GrRard KrefFT}

P.S. The trustees have had so many applications for Ceratodus specimens, and they have been so often disappointed when exchanging them with other museums, that they have now determined to sell their duplicates in London to the highest bidders. Five of these fishes, in spirits (males and females) will be despatched to Messrs. P. W. Flower and Sons, and I hope that a good price will be obtained for them. Up to the present time all efforts to obtain more of the Ceratodus have been in vain, and I believe that they are not so common as some people think. Mr. George Masters has too much to do here ; and besides, we have no funds, travelling being very expensive in the Wide Bay district, otherwise another Expedition would be sent by the Board. Mr. Masters knows how to catch them, and I hope that when the Chalienger arrives he will be able to accompany a party from that ship to Gayndah.

\section{Rainbow and its Reflexion}

A rEW weeks ago $I$ had the pleasure of seeing a rainbow and its reflexion, or at least a reflexion of one from the same shower at the same time, in smooth water.

The base of the bow in the cloud seemed but a few hundred yards from me, and the reflexion evidently did not belong to it, as the two bases did not correspond, the reflected bow lying inside the other, the red of the one commencing where the violet rays of the other disappeared.

Balbriggan, Ireland, Feb. 2

GEORGE DAWSON

\section{Remarkable Fossils}

The letter by Mr. T. W. Cowan in NATURE, vol. ix. p. 24I, confirms the truth of the statements contained in my "Appeal to our Provincial Scientific Societies" which appeared in NATURE, vol. ix. p. 162. Collections of the kind described by Mr. Cowan are "kicking" about the country in all directions, valued merely as temporary possessions by the owners, few of whom, as far as my experience goes, appear to possess sufficient public spirit or intelligence to realise their public and scientific importance otherwise these coliections would be more frequently localised and preserved for the district museum.

$$
\text { Jan. 3I }
$$

\section{Volcamoes and the Earth's Crust}

Mr. Howorth, in Nature, yol. ix. p. 20I, advances the following opinions:- That volcanoes are found neither in regions of elevation nor of subsidence, but on the bound ries between them; that the great continents are on the whole rising, and the beds of the great oceans on the whole sinking; and that the centres of elevation are in the circumpolar regions.

It seems to me that the last two statements cannot be reconciled with each other. The sonthern hemisphere is for by far the greater part oceanic. According to $\mathrm{Mr}$. Howorth, the ocean-beds are subsiding, and yet the southern circumpolar region contains a focus of elevation. Further: if volcanoes are not found in areas of elevation, and if the circumpolar regions are regions of elevation, what does he make of the volcanoes of Jan Mayen (between Norway and Spitzbergen), and of the Antarctic continent? 